\title{
EVALUASI KINERJAANGKUTAN UMUM PENUMPANG KOTA MALANG PADA JALUR GA (HAMID RUSDI - ARJOSARI)
}

\author{
Tri Asmaraning Tyas A M', Alik Ansyori, ${ }^{2}$ \\ 1,2Jurusan Teknik Sipil Fakultas Teknik - Universitas Muhammadiyah Malang \\ Alamat korespondensi : Jalan Raya Tlogomas 246 Malang 65144
}

\begin{abstract}
Public transport passengers in Malang commonly called public transportation or public transit is on of the means of transport that is often used by people to perform daily activities - day, but public transport passengers in the city of Malang is now often seen to cause problems and disturt traffic. The purpose of this study was to determine the level of service of public transport passangers GA pathway. The method used is the empirical methods that include surveys of static and dynamic survey. The results of the performance study of public transit passanger load factor pathway GA earned an average of $189,15 \%$, the average frequency of $62 \mathrm{kend} / \mathrm{h}$, average time headway of 1,0 minutes, average travel speed of $16,44 \mathrm{~km} / \mathrm{h}$.
\end{abstract}

Keywords : Performance Evaluation of Public Transport Passengers

\begin{abstract}
Abstrak
Penumpang umum transportasi di Malang yang biasa disebut transportasi umum atau angkutan umum adalah sarana transportasi yang sering digunakan oleh orang-orang untuk melakukan kegiatan sehari - hari, tapi penumpang angkutan umum di kota Malang kini sering menjadi penyebabmasalah dan mengganggu lalu lintas. Tujuan dari penelitian ini adalah untuk mengetahui tingkat pelayanan penumpang angkutan umum GA jalur. Metode yang digunakan adalah metode empiris yang mencakup survei survei statis dan dinamis. Hasil studi kinerja angkutan umum load factor penumpang jalur GA diperoleh rata-rata $189,15 \%$, frekuensi rata-rata $62 \mathrm{kend} / \mathrm{jam}$, rata-rata waktu headway 1,0 menit, kecepatan tempuh rata-rata $16,44 \mathrm{~km} / \mathrm{h}$.
\end{abstract}

Kata kunci : Evaluasi Kinerja Angkutan Umum Penumpang

\section{PENDAHULUAN}

Angkutan umum penumpang di Kota Malang yang biasa disebut angkutan kota adalah salah satu sarana transportasi yang digunakan untuk melayani aktifitas masyarakat di Kota Malang. Angkutan umum penumpang seakan menjadi urat peredaran ekonomi di Kota Malang. Meskipun saat ini volume jumlah penumpang pengguna jasa angkutan umum penumpang yang semakin hari semakin berkurang, namun angkutan umum penumpang masih dibutuhkan oleh masyarakat Kota Malang dalam melakukan aktifitas sehari-hari.

Jalur GA (Hamid Rusdi - Arjosari) adalah angkutan umum penumpang kota Malang yang beroperasi melayani penumpang dari terminal Hamid Rusdi ke terminal Arjosari maupun sebaliknya. Panjang rute angkutan umum penumpang $\mathrm{GA} \pm 16$
Km. Sesuai kesepakatan BPTD (Badan Pertimbangan Transportasi Daerah) dengan paguyuban jalur Angkutan umum penumpang kota Malang, tarif angkutan GA Rp 2.300 untuk umum dan Rp. 1500 untuk pelajar. Jumlah armada jalur GA sampai tahun 2012 adalah 160 kendaraan.

Angkutan umum penumpang GA beroperasi rata - rata 6 pulang pergi (PP) atau 12 rit perjalanan setiap harinya. Setiap kali berangkat angkutan umum penumpang GA mengisi tempat duduk dengan rata - rata 12 penumpang. Waktu yang ditempuh angkutan umum penumpang GA sekitar \pm 1 jam. Selain itu karena headway yang terkadang cepat terasa kurang efektif, sehingga pengemudi sering menggunakan waktu untuk mengangkut dan menurunkan penumpang dijalan, hal ini juga sangat berpengaruh terhadap kecepatan perjalanan $(\mathrm{Km} /$ Jam), dan waktu perjalanan (Jam). 
Permasalahan yang terjadi adalah besarnya jumlah kendaraan sangat berpengaruh terhadap jarak keberangkatan Aangkutan Umum Penumpang jalur GA, Jarak keberangkatan (headway) yang dekat berpengaruh terhadap jumlah penumpang, Waktu tempuh AUP jalur GA \pm 1 jam dengan jarak tempuh $\pm 16 \mathrm{Km}$.

Sedangkan tujuan dari studi ini adalah untuk mengetahui tingkat kinerja angkutan umum penumpang jalur GA.

\section{METODE PENELITIAN}

\section{Wilayah Studi}

Rute Angkutan umum penumpang Jalur GA Dari Terminal Hamid Rusdi - Terminal Arjosari :

Terminal Hamid Rusdi (Jl. Mayjen Sungkono) - Jl. Raya Gadang -- Jl. Satsuit Tubun - Jl. S Supriyadi - Jl. Arif Margono - Jl. Ade Irma Suryani - Jl. KH Wahid Hasyim - Jl. Kauman - Jl. Hasyim Asyhari - J1. AR Hakim - Jl. Merdeka Utara - Jl. Mojopahit - Jl. Tugu - Jl. Untung Suropati - Jl. Pajajaran - Jl. Trunojoyo - Jl. Cokroaminito - Jl. Dr Cipto - Jl. Pang Sudirman - Jl. WR Supratman - Jl. Letjent Sutoyo - Jl. Letjend S. Parman - Jl. Jend A. Yani - Jl. Raden Intan - Terminal Arjosari.

Dari Terminal Arjosari - Terminal Hamid Rusdi :

Terminal Arjosari - Jl. Simpang Panji Suroso - Jl. Raden Intan - Jl. Jend A. Yani - Jl. Letjend S Parman - Jl. Letjend Sutoyo - Jl. Indragiri Jl. Mahakam - Jl. WR Supratman - Jl. Pang Sudirman - JL. Patimura - Jl. Truno Joyo Jl. Kertanegara - Jl. Tugu - Jl. Mojopahit - Jl. Merdeka Timur - Jl.SW Pranoto - J1. Sutan Syahrir - Jl. Halmahera - Jl. Tanimbar - Jl.
Sulawesi - Jl. Nusa Kambangan - Jl. Arif Margono - Jl. S Supriyadi - Jl. Satsuit Tubun - Jl. Raya Gadang - Terminal Hamid Rusdi (Jl. Mayjen Sungkono).

\section{Pembagian Zona}

Pembagian zona digunakan untuk mempermudah didalam pengambilan data naik turun penumpang sesuai dengan asal tujuan. Zona tersebut dibagi dalam 8 zona, adapun kedelapan zona tersebut disajikan pada tabel 1 dan 2

Tabel 1. Pembagian Zona AUP jalur GA (Hamid Rusdi - Arjosari)

\begin{tabular}{cl}
\hline Zona & \multicolumn{1}{c}{ Lokasi Pengamatan } \\
\hline 1 & Terminal Hamid Rusdi - Simp. Kacuk \\
2 & Simp. Kacuk - Pasar Sukun \\
3 & Pasar Sukun - Simp. Ade Irma S \\
4 & Simp. Ade Irma S - Simp. Merdeka \\
& Timur \\
5 & Simp. Merdeka Timur - Pasar Klojen \\
6 & Pasar Klojen - Simp SMP 5 \\
7 & Simp. SMP 5 - Masjid Sabilillah \\
8 & Masjid Sabilillah - Terminal Arjosari \\
\hline
\end{tabular}

Tabel 2 Pembagian Zona AUP Jalur GA (Arjosari - Hamid Rusdi)

\begin{tabular}{cl}
\hline Zona & \multicolumn{1}{c}{ Lokasi Pengamatan } \\
\hline 1 & Terminal Arjosari - Masjid \\
& Sabilillah \\
2 & Masjid Sabilillah - Simp. SMP 5 \\
3 & Simp. SMP 5 - Stasiun Kota Baru \\
4 & Stasiun Kota Baru - Trend Shop \\
5 & Trend Shop - RS. Sopraoen \\
6 & RS. Sopraoen - Simp. Janti Barat \\
7 & Simp. Janti Barat - Simp. Kacuk \\
8 & Simp. Kacuk - Terminal Hamid \\
& Rusdi \\
\hline
\end{tabular}

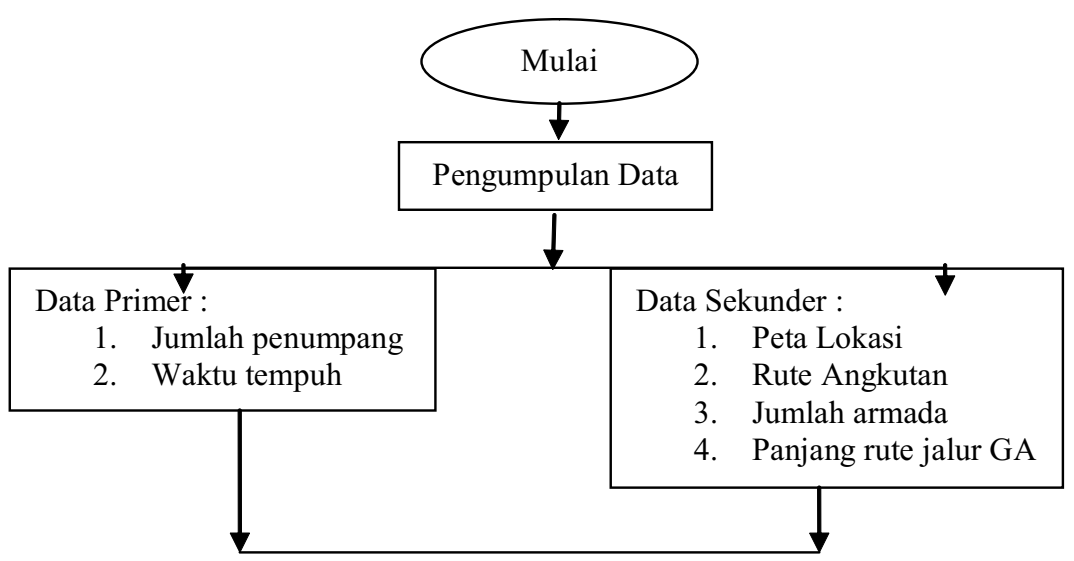




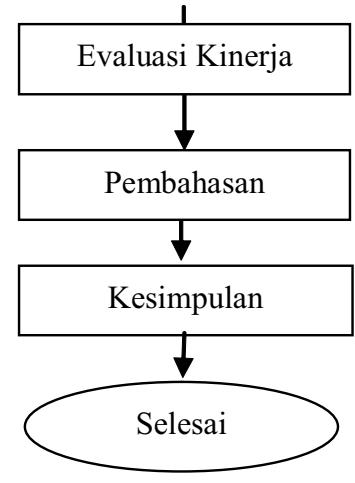

Gambar 1. Diagram alir tahapan studi

\section{Data Primer dan Data Sekunder}

Data primer yang dikumpulkan adalah jumlah penumpang dan waktu tempuh Angkutan Umum Penumpang jalur GA. Sedangkan data sekunder yang dikumpulkan, antara lain : Peta lokasi, rute angkutan, jumlah kendaraan/ armada, dan panjang rute. Survey ini dilakukan dengan mencatat jumlah kendaraan yang lewat dilokasi pengamatan.

Parameter kinerja angkutan umum penumpang jalur GA meliputi: Tingkat Pengisian (Load Faktor), Jarak Antara (headway), Frekuensi, Waktu tempuh.

\section{HASIL DAN PEMBAHASAN}

Panjang rute angkutan umum penumpang jalur $\mathrm{GA} \pm 16 \mathrm{~km}$, jumlah armada angkutan umum penumpang GA sebanyak 160 unit, data jumlah penumpang dan waktu tempuh disajikan pada tabel 3 dan 4, data pola naik turun penumpang disajikan pada tabel 5 dan 6 , dan jumlah kendaraan di jalan disajikan pada tabel3..

Tabel 3 Data penumpang dan waktu tempuh AUP GA arah Hamid Rusdi-Arjosari

\begin{tabular}{|c|c|c|c|c|c|c|c|c|c|}
\hline \multirow{3}{*}{$\begin{array}{c}\text { Jam } \\
\text { Berangkat }\end{array}$} & \multicolumn{3}{|c|}{ Selasa } & \multicolumn{3}{|c|}{ Rabu } & \multicolumn{3}{|c|}{ Kamis } \\
\hline & \multicolumn{2}{|c|}{ Penumpang } & \multirow{2}{*}{$\begin{array}{l}\text { WaktuTempuh } \\
\text { (menit) }\end{array}$} & \multicolumn{2}{|c|}{ Penumpang } & \multirow{2}{*}{$\begin{array}{l}\text { WaktuTempuh } \\
\text { (menit) }\end{array}$} & \multicolumn{2}{|c|}{ Penumpang } & \multirow{2}{*}{$\begin{array}{l}\text { WaktuTempuh } \\
\text { (menit) }\end{array}$} \\
\hline & Umum & Pelajar & & Umum & Pelajar & & Umum & Pelajar & \\
\hline 06.00 & 25 & 5 & 58 & 21 & 5 & 58 & 22 & 3 & 58 \\
\hline 06.30 & 25 & 2 & 64 & 20 & 4 & 57 & 23 & 5 & 65 \\
\hline 07.00 & 23 & 0 & 59 & 20 & 0 & 56 & 23 & 2 & 61 \\
\hline 08.00 & 23 & 0 & 59 & 24 & 0 & 58 & 23 & 0 & 58 \\
\hline 08.30 & 26 & 0 & 61 & 19 & 0 & 60 & 16 & 0 & 59 \\
\hline 10.00 & 19 & 0 & 58 & 19 & 0 & 59 & 15 & 0 & 59 \\
\hline 11.00 & 18 & 0 & 59 & 21 & 0 & 57 & 16 & 0 & 58 \\
\hline 12.00 & 22 & 4 & 59 & 26 & 0 & 59 & 21 & 1 & 59 \\
\hline 12.30 & 22 & 0 & 59 & 22 & 1 & 56 & 19 & 0 & 58 \\
\hline 13.00 & 27 & 0 & 55 & 22 & 6 & 58 & 16 & 0 & 56 \\
\hline 13.30 & 24 & 0 & 55 & 23 & 0 & 58 & 16 & 0 & 55 \\
\hline 14.00 & 19 & 0 & 54 & 23 & 0 & 57 & 14 & 0 & 54 \\
\hline 15.00 & 21 & 0 & 56 & 21 & 0 & 56 & 13 & 0 & 56 \\
\hline 16.00 & 26 & 0 & 55 & 22 & 0 & 59 & 17 & 0 & 57 \\
\hline 17.00 & 23 & 0 & 54 & 22 & 0 & 58 & 16 & 0 & 54 \\
\hline 18.00 & 28 & 0 & 59 & 21 & 0 & 59 & 23 & 0 & 61 \\
\hline
\end{tabular}

Sumber :Hasil survei

Tabel 4 Data penumpang dan waktu tempuh AUP GA arah Arjosari-Hamid Rusdi

\begin{tabular}{|c|c|c|c|c|c|c|c|c|c|}
\hline \multirow{3}{*}{$\begin{array}{c}\text { Jam } \\
\text { Berangkat }\end{array}$} & \multicolumn{3}{|c|}{ Selasa } & \multicolumn{3}{|c|}{ Rabu } & \multicolumn{3}{|c|}{ Kamis } \\
\hline & \multicolumn{2}{|c|}{ Penumpang } & \multirow{2}{*}{$\begin{array}{l}\text { WaktuTempuh } \\
\text { (menit) }\end{array}$} & \multicolumn{2}{|c|}{ Penumpang } & \multirow{2}{*}{$\begin{array}{c}\text { WaktuTempuh } \\
\text { (menit) }\end{array}$} & \multicolumn{2}{|c|}{ Penumpang } & \multirow{2}{*}{$\begin{array}{l}\text { WaktuTempuh } \\
\text { (menit) }\end{array}$} \\
\hline & Umum & Pelajar & & Umum & Pelajar & & Umum & Pelajar & \\
\hline 06.00 & 23 & 2 & 60 & 25 & 6 & 60 & 25 & 2 & 59 \\
\hline 06.30 & 24 & 1 & 57 & 24 & 5 & 65 & 25 & 1 & 63 \\
\hline 07.00 & 22 & 2 & 59 & 25 & 0 & 59 & 26 & 0 & 61 \\
\hline 08.00 & 21 & 0 & 61 & 25 & 0 & 59 & 22 & 0 & 59 \\
\hline
\end{tabular}




\begin{tabular}{llllllllll}
\hline 08.30 & 22 & 0 & 59 & 21 & 0 & 60 & 21 & 0 & 58 \\
10.00 & 19 & 0 & 59 & 21 & 0 & 59 & 23 & 0 & 60 \\
11.00 & 22 & 0 & 57 & 20 & 0 & 59 & 22 & 0 & 59 \\
12.00 & 20 & 5 & 59 & 22 & 2 & 59 & 24 & 5 & 58 \\
12.30 & 20 & 4 & 61 & 21 & 2 & 58 & 21 & 4 & 58 \\
13.00 & 22 & 0 & 58 & 21 & 3 & 57 & 22 & 0 & 59 \\
13.30 & 22 & 0 & 61 & 24 & 0 & 58 & 21 & 0 & 58 \\
14.00 & 18 & 0 & 58 & 22 & 0 & 57 & 21 & 0 & 59 \\
15.00 & 24 & 0 & 59 & 22 & 0 & 56 & 18 & 0 & 61 \\
16.00 & 26 & 0 & 62 & 24 & 0 & 59 & 22 & 0 & 58 \\
17.00 & 27 & 0 & 59 & 26 & 0 & 58 & 26 & 0 & 62 \\
18.00 & 23 & 0 & 59 & 24 & 0 & 62 & 26 & 0 & 62 \\
\hline
\end{tabular}

Sumber :Hasil Survey

Tabel 5 Pola Naik Turun Penumpang Angkutan umum penumpang Jalur GA arah Hamid Rusdi -

\section{Arjosari}

\begin{tabular}{|c|c|c|c|c|c|c|c|c|c|c|c|c|c|c|c|c|c|c|}
\hline \multirow{3}{*}{$\begin{array}{c}\text { Jam } \\
\text { Berang } \\
\text { Kat }\end{array}$} & \multirow{3}{*}{$\begin{array}{c}\text { Kenda } \\
\text { raan }\end{array}$} & \multirow{3}{*}{ Zona } & \multicolumn{15}{|c|}{ Hamid Rusdi - Arjosari } & \multirow{3}{*}{ Maximun } \\
\hline & & & 1 & 2 & \multicolumn{2}{|l|}{3} & \multicolumn{2}{|c|}{4} & \multicolumn{2}{|c|}{5} & \multicolumn{2}{|c|}{6} & \multicolumn{2}{|l|}{7} & \multicolumn{2}{|c|}{8} & \multirow{2}{*}{$\begin{array}{l}\text { To } \\
\text { tal }\end{array}$} & \\
\hline & & & $\mathrm{U} \quad \mathrm{P}$ & $\mathrm{U} \quad \mathrm{P}$ & $\mathrm{U}$ & $\mathrm{P}$ & $\mathrm{U}$ & $\mathrm{P}$ & $\mathrm{U}$ & $\mathrm{P}$ & $\mathrm{U}$ & $\mathrm{P}$ & $\mathrm{U}$ & $\mathrm{P}$ & $\mathrm{U}$ & $\mathrm{P}$ & & \\
\hline \multirow{3}{*}{06.00} & \multirow{2}{*}{1} & naik & 10 & 2 & 2 & & 1 & & 2 & 2 & 2 & 1 & 1 & & 1 & & 26 & \\
\hline & & turun & 2 & 21 & 4 & 1 & 1 & & 3 & & & 3 & 2 & & 7 & & 26 & 10 \\
\hline & Jumlah & & 10 & 9 & 6 & & 6 & & 7 & & & & 6 & & 0 & & & \\
\hline \multirow{3}{*}{06.30} & \multirow{2}{*}{2} & naik & 102 & 2 & 2 & & 1 & & 2 & & & 2 & 3 & & & & 24 & \\
\hline & & turun & 3 & 12 & 2 & & 2 & & 2 & & 2 & 2 & 3 & & 5 & & 24 & 9 \\
\hline & Jumlah & & 9 & 8 & 8 & & 7 & & 7 & & & & 5 & & 0 & & & \\
\hline \multirow{3}{*}{07.00} & \multirow{2}{*}{3} & naik & 12 & 2 & & & 2 & & & & 4 & & & & & & 20 & \\
\hline & & turun & 2 & 2 & 3 & & 3 & & 1 & & & & 2 & & 7 & & 20 & 10 \\
\hline & Jumlah & & 10 & 10 & 7 & & 6 & & 5 & & & & 7 & & 0 & & & \\
\hline \multirow{3}{*}{08.00} & \multirow{2}{*}{4} & naik & 12 & 3 & 2 & & 2 & & 3 & & 2 & & & & & & 24 & \\
\hline & & turun & & 3 & 4 & & 3 & & 2 & & 3 & & 2 & & 7 & & 24 & 12 \\
\hline & Jumlah & & 12 & 12 & 10 & & 9 & & 1 & & & & 7 & & 0 & & & \\
\hline 0830 & 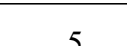 & naik & 6 & 4 & & & 1 & & & & 2 & & 2 & & 4 & & 19 & \\
\hline 0.50 & & turun & 2 & & 2 & & 3 & & & & 2 & & & & 10 & & 19 & 8 \\
\hline & Jumlah & & 4 & 8 & 6 & & 4 & & 4 & & & & 6 & & 0 & & & \\
\hline 1000 & 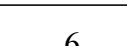 & naik & 10 & 2 & & & 3 & & & & 1 & & 3 & & & & 19 & \\
\hline 10.00 & & turun & & 3 & 1 & & 4 & & 2 & & 3 & & & & 6 & & 19 & 10 \\
\hline & Jumlah & & 10 & 9 & 8 & & 7 & & 5 & & & 3 & 6 & & 0 & & & \\
\hline & & naik & 9 & 4 & 4 & & & & 2 & & & & 2 & & & & 21 & \\
\hline 11.00 & 1 & turun & 3 & 2 & 4 & & 2 & & 3 & & 2 & & 3 & & 2 & & 21 & 8 \\
\hline & Jumlah & & 6 & 8 & 8 & & 6 & & 5 & & & 3 & 2 & & 0 & & & \\
\hline 1200 & 8 & naik & 10 & 2 & 2 & & 3 & & 3 & & 2 & & 2 & & 2 & & 26 & \\
\hline 12.00 & 8 & turun & & 2 & 2 & & 3 & & 4 & & 2 & & 6 & & 7 & & 26 & 10 \\
\hline & Jumlah & & 10 & 10 & 10 & & 10 & & 9 & & & 9 & 5 & & 0 & & & \\
\hline & 9 & naik & 10 & $\begin{array}{ll}5 & 1\end{array}$ & & & 1 & & 3 & & 3 & & & & & & 23 & \\
\hline 12.30 & 9 & turun & 2 & 21 & 4 & & 2 & & 1 & & 3 & & 3 & & 5 & & 23 & 11 \\
\hline & Jumlah & & 8 & 11 & 7 & & 6 & & 8 & & & 8 & 5 & & 0 & & & \\
\hline 1300 & 10 & naik & 10 & $\begin{array}{ll}1 & 4\end{array}$ & 1 & & 3 & & 3 & & 2 & 2 & & & 2 & & 28 & \\
\hline 10.00 & 10 & turun & & 3 & & 1 & 2 & 2 & 2 & 1 & 3 & & 2 & 2 & 7 & & 28 & 12 \\
\hline & Jumlah & & 10 & 12 & 9 & & 8 & & 8 & 8 & & 9 & 5 & & 0 & & & \\
\hline 1330 & 11 & naik & 9 & 2 & 2 & & 2 & & & & 3 & & 4 & & 1 & & 23 & \\
\hline 15.50 & 11 & turun & & 2 & 3 & & 4 & & 2 & & 1 & & 5 & & 6 & & 23 & 9 \\
\hline & Jumlah & & 9 & 9 & 8 & & 6 & & 4 & & & 6 & 5 & & 0 & & & \\
\hline
\end{tabular}




\begin{tabular}{|c|c|c|c|c|c|c|c|c|c|c|c|c|}
\hline \multirow{2}{*}{15.00} & \multirow{2}{*}{13} & naik & 8 & 3 & & & \multicolumn{2}{|l|}{4} & 2 & 4 & \multicolumn{2}{|l|}{21} \\
\hline & & turun & & 3 & 2 & 2 & 2 & 3 & 3 & 6 & 21 & 8 \\
\hline & Jumlah & & 8 & 8 & 6 & 4 & 6 & 3 & 2 & ( & & \\
\hline \multirow{3}{*}{16.00} & \multirow{2}{*}{14} & naik & 9 & 3 & 2 & 1 & 2 & 3 & 2 & & 22 & \\
\hline & & turun & 2 & 3 & 3 & 4 & 1 & 1 & 3 & 5 & 22 & 7 \\
\hline & Jumlah & & 7 & 7 & 6 & 3 & 4 & 6 & 5 & ( & & \\
\hline \multirow{3}{*}{17.00} & \multirow{2}{*}{15} & naik & 9 & 2 & 3 & 3 & 2 & 1 & 2 & & 22 & \\
\hline & & turun & 2 & 2 & 2 & 3 & 4 & 2 & 2 & 5 & 22 & 8 \\
\hline & Jumlah & & 7 & 7 & 8 & 8 & 6 & 5 & 5 & ( & & \\
\hline \multirow{3}{*}{18.00} & \multirow{2}{*}{16} & naik & 10 & 4 & 1 & & 3 & 2 & 1 & & 21 & \\
\hline & & turuın & 3 & & 2 & 3 & 1 & 2 & 4 & 6 & 21 & 11 \\
\hline & Jumlah & & 7 & 11 & 10 & 7 & 9 & 9 & 6 & ( & & \\
\hline
\end{tabular}

Sumber : Hasil Survey

Tabel 6 Pola Naik Turun Penumpang Angkutan umum penumpang Jalur GA arah Arjosari - Hamid Rusdi

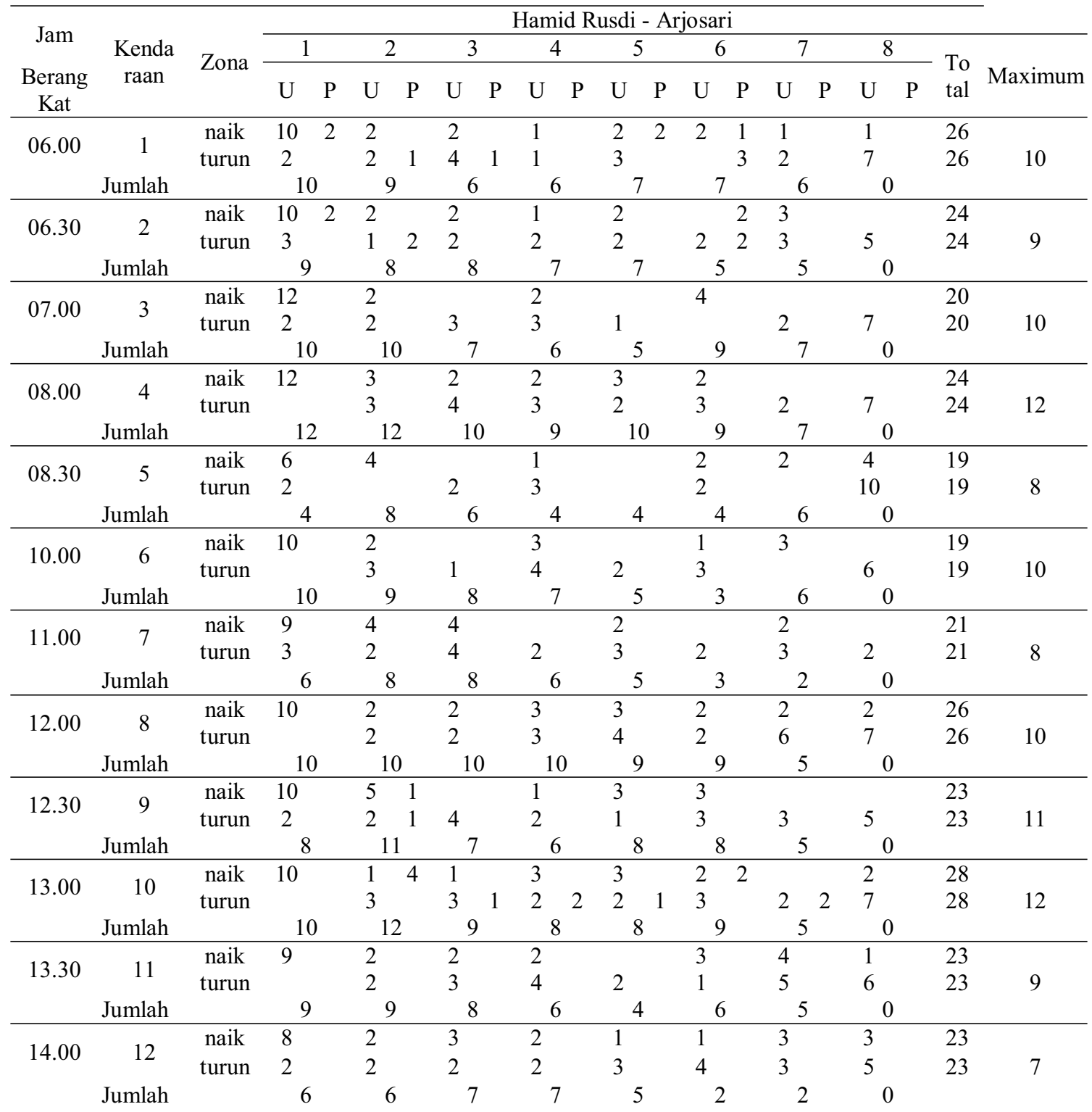




\begin{tabular}{|c|c|c|c|c|c|c|c|c|c|c|c|c|}
\hline \multirow[t]{2}{*}{15.00} & 13 & \multirow[t]{2}{*}{$\begin{array}{c}\text { naik } \\
\text { turun }\end{array}$} & \multirow{2}{*}{$\begin{array}{l}8 \\
8 \\
8 \\
\end{array}$} & $\begin{array}{l}3 \\
3\end{array}$ & 2 & 2 & \multicolumn{2}{|l|}{4} & $\begin{array}{l}2 \\
3\end{array}$ & $\begin{array}{l}4 \\
6\end{array}$ & \multirow[t]{2}{*}{$\begin{array}{l}21 \\
21\end{array}$} & \multirow[t]{2}{*}{8} \\
\hline & Jumlah & & & 8 & 6 & 4 & 6 & 3 & 2 & 0 & & \\
\hline \multirow{3}{*}{16.00} & \multirow{2}{*}{14} & naik & 9 & 3 & 2 & 1 & 2 & 3 & 2 & & 22 & \\
\hline & & turun & 2 & 3 & 3 & 4 & 1 & 1 & 3 & 5 & 22 & 7 \\
\hline & Jumlah & & 7 & 7 & 6 & 3 & 4 & 6 & 5 & 0 & & \\
\hline \multirow{3}{*}{17.00} & \multirow{2}{*}{15} & naik & 9 & 2 & 3 & 3 & 2 & 1 & 2 & & 22 & \\
\hline & & turun & 2 & 2 & 2 & 3 & 4 & 2 & 2 & 5 & 22 & 8 \\
\hline & Jumlah & & 7 & 7 & 8 & 8 & 6 & 5 & 5 & 0 & & \\
\hline \multirow{3}{*}{18.00} & \multirow{2}{*}{16} & naik & 10 & 4 & 1 & & 3 & 2 & 1 & & 21 & \\
\hline & & turun & 3 & & 2 & 3 & 1 & 2 & 4 & 6 & 21 & 11 \\
\hline & Jumlah & & 7 & 11 & 10 & 7 & 9 & 9 & 6 & 0 & & \\
\hline
\end{tabular}

Sumber:Hasil Survey

Tabel 7 Jumlah Kendaraan Angkutan umum penumpang GA

\begin{tabular}{|c|c|c|c|c|c|c|}
\hline \multirow{2}{*}{$\begin{array}{c}\text { Arah } \\
\text { Hari } \\
\text { Jam }\end{array}$} & \multicolumn{3}{|c|}{ Hamid Rusdi - Arjosari } & \multicolumn{3}{|c|}{ Arjosari - Hamid Rusdi } \\
\hline & Selasa & Rabu & Kamis & Selasa & Rabu & Kamis \\
\hline $06.00-06.15$ & 14 & 15 & 14 & 15 & 15 & 13 \\
\hline $06.15-06.30$ & 14 & 16 & 15 & 14 & 18 & 14 \\
\hline $06.30-06.45$ & 16 & 17 & 16 & 16 & 17 & 16 \\
\hline $06.45-07.00$ & 15 & 17 & 15 & 15 & 17 & 14 \\
\hline $07.00-07.15$ & 15 & 16 & 14 & 14 & 16 & 14 \\
\hline $07.00-07.30$ & 17 & 18 & 13 & 17 & 18 & 16 \\
\hline $07.30-07.45$ & 17 & 17 & 17 & 16 & 17 & 16 \\
\hline $07.45-08.00$ & 16 & 17 & 15 & 17 & 14 & 14 \\
\hline $08.00-08.15$ & 13 & 15 & 14 & 13 & 13 & 14 \\
\hline $08.15-08.30$ & 14 & 14 & 14 & 14 & 14 & 14 \\
\hline $08.30-08.45$ & 15 & 14 & 13 & 14 & 15 & 15 \\
\hline $08.45-09.00$ & 15 & 15 & 16 & 16 & 15 & 15 \\
\hline $09.00-09.15$ & 15 & 15 & 15 & 15 & 15 & 15 \\
\hline $09.00-09.30$ & 17 & 16 & 16 & 15 & 17 & 17 \\
\hline $09.30-09.45$ & 16 & 16 & 15 & 16 & 15 & 16 \\
\hline $09.45-10.00$ & 14 & 15 & 14 & 15 & 14 & 14 \\
\hline $10.00-10.15$ & 14 & 14 & 16 & 15 & 14 & 14 \\
\hline $10.15-10.30$ & 15 & 14 & 14 & 15 & 15 & 13 \\
\hline $10.30-10.45$ & 13 & 15 & 14 & 14 & 15 & 14 \\
\hline $10.45-11.00$ & 14 & 16 & 14 & 14 & 14 & 14 \\
\hline $11.00-11.15$ & 16 & 16 & 16 & 16 & 13 & 16 \\
\hline $11.15-11.30$ & 15 & 15 & 14 & 15 & 15 & 15 \\
\hline $11.30-11.45$ & 14 & 13 & 13 & 14 & 16 & 14 \\
\hline $11.45-12.00$ & 14 & 14 & 16 & 14 & 14 & 14 \\
\hline $12.00-12.15$ & 16 & 17 & 16 & 17 & 16 & 16 \\
\hline $12.15-12.30$ & 16 & 14 & 15 & 16 & 16 & 16 \\
\hline $12.30-12.45$ & 16 & 17 & 15 & 17 & 17 & 16 \\
\hline $12.45-13.00$ & 15 & 17 & 15 & 15 & 15 & 15 \\
\hline $13.00-13.15$ & 17 & 16 & 16 & 17 & 17 & 17 \\
\hline $13.15-13.30$ & 15 & 16 & 16 & 16 & 17 & 15 \\
\hline $13.30-13.45$ & 15 & 16 & 16 & 16 & 16 & 15 \\
\hline $13.45-14.00$ & 15 & 15 & 15 & 16 & 16 & 15 \\
\hline $14.00-14.15$ & 16 & 16 & 14 & 16 & 16 & 16 \\
\hline $14.15-14.30$ & 17 & 15 & 15 & 17 & 17 & 17 \\
\hline $14.30-14.45$ & 14 & 16 & 14 & 14 & 14 & 14 \\
\hline $14.45-15.00$ & 14 & 15 & 14 & 15 & 14 & 14 \\
\hline $15.00-15.15$ & 15 & 15 & 16 & 15 & 15 & 15 \\
\hline $15.15-15.30$ & 14 & 16 & 15 & 14 & 15 & 15 \\
\hline $15.30-15.45$ & 16 & 16 & 16 & 16 & 16 & 16 \\
\hline $15.45-16.00$ & 15 & 17 & 15 & 15 & 16 & 15 \\
\hline $16.00-16.15$ & 17 & 17 & 16 & 17 & 17 & 17 \\
\hline
\end{tabular}




\begin{tabular}{lllllll}
\hline $16.15-16.30$ & 16 & 17 & 16 & 18 & 16 & 16 \\
$16.30-16.45$ & 18 & 17 & 17 & 16 & 18 & 18 \\
$16.45-17.00$ & 16 & 16 & 16 & 16 & 16 & 16 \\
$17.00-17.15$ & 15 & 16 & 16 & 15 & 16 & 15 \\
$17.15-17.30$ & 16 & 16 & 16 & 17 & 16 & 16 \\
$17.30-17.45$ & 15 & 16 & 15 & 15 & 15 & 16 \\
$17.45-18.00$ & 15 & 17 & 16 & 16 & 16 & 15 \\
\hline
\end{tabular}

Sumber: Hasil Survey

\section{Kinerja Angkutan Umum Penumpang jalur GA Load factor (LF) angkutan umum penumpang Load Factor (Faktor Muat) jalur GA kondisi eksisting disajikan pada tabel 8 .}

Tabel 8 Load Factor Angkutan umum penumpang Jalur GA

\begin{tabular}{|c|c|c|c|c|c|c|}
\hline \multirow{3}{*}{$\begin{array}{c}\text { Jam } \\
\text { Berangkat }\end{array}$} & \multicolumn{6}{|c|}{ Load Faktor (\%) } \\
\hline & \multicolumn{3}{|c|}{ Hamid Rusdi - Arjosari } & \multicolumn{3}{|c|}{ Arjosari - Hamid Rusdi } \\
\hline & Selasa & Rabu & Kamis & Selasa & Rabu & Kamis \\
\hline 06.00 & 250,00 & 216,67 & 208,33 & 208,33 & 258,33 & 225,00 \\
\hline 06.30 & 225,00 & 200,00 & 233,33 & 208,33 & 241,67 & 216,67 \\
\hline 07.00 & 191,67 & 166,67 & 208,33 & 200,00 & 208,33 & 216,67 \\
\hline 08.00 & 191,67 & 200,00 & 191,67 & 175,00 & 208,33 & 183,33 \\
\hline 08.30 & 216,67 & 158,33 & 133,33 & 183,33 & 175,00 & 175,00 \\
\hline 10.00 & 158,33 & 158,33 & 125,00 & 158,33 & 175,00 & 191,67 \\
\hline 11.00 & 150,00 & 175,00 & 133,33 & 183,33 & 166,67 & 183,33 \\
\hline 12.00 & 216,67 & 216,67 & 183,33 & 208,33 & 200,00 & 241,67 \\
\hline 12.30 & 183,33 & 191,67 & 158,33 & 200,00 & 191,67 & 208,33 \\
\hline 13.00 & 225,00 & 233,33 & 133,33 & 183,33 & 200,00 & 183,33 \\
\hline 13.30 & 200,00 & 191,67 & 133,33 & 183,33 & 200,00 & 175,00 \\
\hline 14.00 & 158,33 & 191,67 & 116,67 & 150,00 & 183,33 & 175,00 \\
\hline 15.00 & 175,00 & 175,00 & 108,33 & 200,00 & 183,33 & 150,00 \\
\hline 16.00 & 216,67 & 183,33 & 141,67 & 216,67 & 200,00 & 183,33 \\
\hline 17.00 & 191,67 & 183,33 & 133,33 & 225,00 & 216,67 & 216,67 \\
\hline 18.00 & 233,33 & 175,00 & 191,67 & 191,67 & 200,00 & 216,67 \\
\hline Maksimum & 250,00 & 216,67 & 233,33 & 208,33 & 258,33 & 241,67 \\
\hline Minimum & 150,00 & 166,67 & 108,33 & 150,00 & 166,67 & 150,00 \\
\hline Rata-rata & 198,96 & 188,54 & 158,33 & 192,19 & 200,52 & 196,35 \\
\hline Maksimum & & 250,00 & & & 258,33 & \\
\hline Minimum & & 108,33 & & & 150,00 & \\
\hline Rata-rata & & 181,94 & & & 196,35 & \\
\hline Maksimum & \multicolumn{6}{|c|}{258,33} \\
\hline Minimum & \multicolumn{6}{|c|}{108,33} \\
\hline Rata-rata & \multicolumn{6}{|c|}{189,15} \\
\hline
\end{tabular}

Sumber : Hasil perhitungan

Load Factor tertinggi terjadi pada hari Rabu jam keberangkatan 06.00 sebesar $258,33 \%$ dari arah Arjosari - Hamid Rusdi, sedangkan LF terendah terjadi pada hari Kamis jam keberangkatan 15.00 sebesar 108,33\% dari arah Hamid Rusdi - Arjosari, Adapun LF rata-rata didapat sebesar 189,15\%.

\section{Frekuensi}

Frekuensi AUP jalur GA di jalan tertinggi terjadi pada hari Rabu jam 06.30 - 08.00 dan $15.45-16.45$ dari arah Hamid Rusdi - Arjosari dan pada jam 06.15 - 07.45 untuk arah Arjosari - Hamid Rusdi sebesar $68 \mathrm{kend} / \mathrm{jam}$, frekuensi terendah terjadi pada hari Kamis jam 09.45 - 11.00 dari arah Arjosari - Hamid Rusdi sebesar 55 kend/jam, sedangkan frekuensi rata-rata angkutan umum penumpang jalur GA dari dua arah (Hamid Rusdi - Arjosai dan Arjosari Hamid Rusdi) sebesar 62 kend/jam.

Hasil perhitungan Frekuensi angkutan umum penumpang jalur GA di jalan disajikan pada tabel 9 . 
Tabel 9 Frekuensi Rata - rata Angkutan umum penumpang Jalur GA (Kend/jam).

\begin{tabular}{|c|c|c|c|c|c|c|}
\hline & \multicolumn{3}{|c|}{ Hamid Rusdi - Arjosari } & \multicolumn{3}{|c|}{ Arjosari - Hamid Rusdi } \\
\hline & Selasa & Rabu & Kamis & Selasa & Rabu & Kamis \\
\hline Maksimum & 1,07 & 1,03 & 1,07 & 1,05 & 1,07 & 1,09 \\
\hline Minimum & 0,90 & 0,88 & 0,92 & 0,90 & 0,88 & 0,90 \\
\hline Rata - rata & 0,98 & 0,95 & 1,0 & 0,97 & 0,96 & 0,99 \\
\hline Maksimum & & 1,07 & & & 1,09 & \\
\hline Minimum & & 0,88 & & & 0,88 & \\
\hline Rata - rata & & 0,98 & & & 0,97 & \\
\hline Maksimum & \multicolumn{6}{|c|}{1,09} \\
\hline Minimum & \multicolumn{6}{|c|}{0,88} \\
\hline Rata - rata & \multicolumn{6}{|c|}{1,0} \\
\hline
\end{tabular}

Sumber : Hasil Perhitungan

Headway waktu rata - rata tertinggi terjadi pada hari Kamis jam 09.45 - 10.45 dari arah Arjosari Hamid Rusdi sebesar 1,09 menit, headway waktu rata - rata terendah terjadi pada hari Rabu jam 06.30 - 08.00 dan 15.45 - 16.45 dari arah Hamid Rusdi Arjosari dan jam 06.15 - 07.45 dari arah Arjosari Hamid Rusdi sebesar 0,88 menit, sedangkan headway waktu rata-rata angkutan umum

Tabel 10. Kecepatan Tempuh Rata - rata Angkutan umum penumpang Jalur GA penumpang jalur GA dari dua arah (Hamid Rusdi Arjosai dan Arjosari - Hamid Rusdi) sebesar 1,0 menit.

\section{Kecepatan Tempuh}

Hasil perhitungan Kecepatan Tempuh AUP jalur GA disajikan pada tabel 10.

\begin{tabular}{|c|c|c|c|c|c|c|}
\hline & \multicolumn{3}{|c|}{ Hamid Rusdi - Arjosari } & \multicolumn{3}{|c|}{ Arjosari - Hamid Rusdi } \\
\hline & selasa & Rabu & Kamis & Selasa & Rabu & Kamis \\
\hline Maximum & 17,78 & 17,14 & 17,78 & 16,84 & 17,14 & 16,55 \\
\hline Minimum & 15,00 & 16,27 & 15,74 & 15,48 & 14,77 & 15,24 \\
\hline Rata - rata & 16,66 & 16,61 & 16,76 & 16,21 & 16,27 & 16,11 \\
\hline Maximum & & 17,78 & & & 17,14 & \\
\hline Minimum & & 15,00 & & & 14,77 & \\
\hline Rata - rata & & 16,68 & & & 16,20 & \\
\hline Maximum & \multicolumn{6}{|c|}{17,78} \\
\hline Minimum & \multicolumn{6}{|c|}{14,77} \\
\hline Rata - rata & \multicolumn{6}{|c|}{16,44} \\
\hline
\end{tabular}

Sumber Hasil Perhitungan

Kecepatan tempuh tertinggi terjadi pada hari Selasa dan Kamis keberangkatan jam 14.00 dan 17.00 sebesar 17.78 km/jam dari arah Hamid Rusdi - Arjosari, kecepatan tempuh terendah terjadi pada hari Rabu keberangkatan jam 06.30 sebesar 14.77 $\mathrm{km} / \mathrm{jam}$ dari arah Arjosari - Hamid Rusdi. Kecepatan tempuh rata-rata dari arah Hamid Rusdi sebesar $16.68 \mathrm{~km} / \mathrm{jam}$ dan kecepatan tempuh ratarata dari arah Arjosari - Hamid Rusdi sebesar 16.20 $\mathrm{km} / \mathrm{jam}$, maka didapatkan kecepatan tempuh ratarata dari Hamid Rusdi - Arjosari dan Arjosari Hamid Rusdi sebesar 16.44 km/jam.

\section{Tinjauan Keseimbangan Supply dan Demand}

Berdasarkan data pola naik turun penumpang pada jam sibuk diketahui penumpang maksimum sebanyak 12 penumpang dan penumpang minimum sebanyak 6 penumpang, pada jam non sibuk diketahui penumpang maksimum sebanyak 10 penumpang dan penumpang minimum sebanyak 4 penumpang. Sedangkan pada kenyataannya dari zona awal sampai zona akhir tidak terlihat penumpang yang tidak terangkut selama perjalanan karena pergerakan naik turunnya penumpang. Ditinjau dari total penumpang pada masing - masing angkutan umum penumpang, jumlah angkutan umum penumpang GA sebanyak 160 unit bisa melayani penumpang untuk demand / permintaan yang ada sekarang.

\section{Pembahasan}

Berdasarkan armada sebanyak 160 unit, load faktor rata - rata sebesar $189,15 \%$, frekuensi rata - rata sebesar $62 \mathrm{kend} / \mathrm{jam}$, headway waktu rata - 
rata sebesar 0,98 menit, waktu tempuh rata - rata sebesar 58 menit ( 0,97 jam ) serta berdasarkan pola naik turun penumpang pada jam sibuk maksimum sebesar 12 penumpang dan minimum sebesar 6 penumpang, kondisi seperti itu angkutan umum penumpang GA tidak terjadi kelebihan penumpang yang artinya tidak ada calon penumpang yang tidak terlayani. Ditinjau dari frekuensi dan headway calon penumpang tidak perlu menunggu angkutan umum penumpang terlalu lama, kecepatan dan waktu tempuh dipengaruhi oleh kondisi kepadatan arus lalu lintas karena angkutan umum penumpang ini melewati rute - rute padat lalu lintas, serta load factor rata - rata dan total penumpang pada masing - masing angkutan umum penumpang yang relatif besar maka angkutan umum penumpang jalur GA masih bisa melayani permintaan (demand) penumpang yang ada sampai saat ini.

\section{KESIMPULAN DAN SARAN}

Kinerja Angkutan Umum Penumpang jalur GA saat ini adalah : frekuensi rata - rata sebesar 62 $\mathrm{kend} / \mathrm{jam}$, headway waktu rata - rata sebesar 1,0 menit, load factor rata - rata angkutan umum penumpang jalur GA sebesar 189,15\%, kecepatan tempuh rata - rata sebesar $16,44 \mathrm{~km} / \mathrm{jam}$, dan waktu tempuh rata - rata sebesar 58 menit $(0,97$ jam).

\section{DAFTAR PUSTAKA}

Direktorat Jenderal Perhubungan Darat. 1996. Pedoman Teknis Penyelenggaraan Angkutan Penumpang Umum Di Wilayah Perkotaan Dalam Trayek Tetap dan Teratur.

Asikin, Muslich Z. 2001. Sistem Manajemen Transportasi Kota. Yogjakarta : Philosophy Prees.

Munawar, Ahmad. 2005. Dasar - Dasar Teknik Transportasi. Jogjakarta : Beta Offset.

Morlok, Edward K. 1978. Pengantar Teknik dan Perencanaan Transportasi. Terjemahan oleh Johan K.Hainim. 1995. Jakarta : Erlangga.

Salim Abbas, A.H. 1993. Manajemen Transportasi. Jakarta : PT. Raja Grafindo Persada.

Warpani, Suwardjoko. 1990. Merencanakan Sistem Perangkutan. Bandung : Penerbit ITB.
Warpani, Suwardjoko. 2002. Pengelolaan Lalu Lintas dan Angkutan Jalan. Bandung :Penerbit ITB. 